JIKAP PGSD: Jurnal Ilmiah IlmuKependidikan

Vol, 4. No,1. Tahun 2020

e-ISSN: 2597-4440 dan p-ISSN: 2597-4424

This work is licensed under a Creative Commons Attribution

4.0 International License

\title{
Media Podcast terhadap Kemampuan Menyimak
}

\author{
Muhammad Asrul Sultan ${ }^{1}$, Nurabidah Idrus $^{2}$, Alfianti Akhmad ${ }^{3}$ \\ 1,2,3 Program Studi PGSD, Fakultas Ilmu Pendidikan, Universitas Negeri Makassar \\ Email: ${ }^{1}$ m.asrul.sultan@unm.ac.id \\ ${ }^{2}$ nurabidahidrus@gmail.com \\ $\underline{3 \text { alfiantiakhmad.ipa1@gmail.com }}$
}

\begin{abstract}
Abstrak. Penelitian ini bertujuan untuk mengetahui pengaruh media podcast terhadap kemampuan menyimak cerita pada mata pelajaran bahasa Indonesia di kelas IV SD Negeri 55 Parepare. Penelitian ini menggunakan pendekatan kuantitatif dengan jenis penelitian eksperimen dan menggunakan desain Quasy Experimental dalam bentuk The Nonequivalent Pretest-Posttest Control Group Design. Teknik sampling yang digunakan dalam penelitian ini adalah purposive sampling dengan jumlah sampel yaitu 46 orang siswa. Teknik pengumpulan data yang digunakan dalam penelitian ini adalah tes dalam bentuk pilihan ganda dan dokumentasi. Analisis data menggunakan teknik analisis statistik deskriptif dan teknik analisis statistik inferensial. Pada pengujian hipotesis dalam analis is statistik inferensial menggunakan uji Paired Sample T-test. Kesimpulan dalam penelitian ini adalah media podcast berpengaruh terhadap peningkatan kemampuan menyimak pada mata pelajaran bahasa Indonesia siswa kelas IV SD Negeri 55 Parepare.
\end{abstract}

Kata kunci: media podcast, kemampuan menyimak

\begin{abstract}
The objective of this research was to determine the effect of podcast media on the listening comprehension on subjects Bahasa Indonesia in class IV SD Negeri Parepare. This research uses a quantitative approach to the type of experimental research and uses the Quasy Experimental design in the form of The Nonequivalent Pretest-Posttest Control Group Design. The sampling technique used was purposive sampling with a sample of 46 students. Data collection techniques used in this research are tests in the form of multiple choices and documentation. Data analysis used descriptive statistical analysis techniques and inferential statistical analysis techniques. In testing the hypothesis in inferential statistical analys is using the Paired Sample T-test. The result is that podcast media affects the increase in listening comprehension on subjects Bahasa Indonesia in class IV SD Negeri 55 Parepare.
\end{abstract}

Keywords: podcast media, listening comprehension

\section{PENDAHULUAN}

Bahasa merupakan sesuatu yang tidak dapat dipisahkan dari kehidupan manusia, sebagai makhluk sosial bahasa menjadi penyatu manusia untuk saling berinteraksi dan berkomunikasi satu sama lain. Manusia dalam kehidupan berkomunikasinya tentu harus memperhatikan dan menerapkan berbagai etika agar terwujud masyarakat yang damai.

Menurut Peraturan Menteri Pendidikan Nasional No. 22 Tahun 2013 bahwa: pendidikan bahasa Indonesia di lembaga formal dimulai dari sekolah dasar. Tujuan khusus pengajaran bahasa Indonesia dikemukakan oleh Susanto (2013) untuk melatih kemampuan menyimak, berbicara, 
membaca dan menulis yang keempatnya saling erat kaitannya. Menyimak mempunyai peranan yang sangat penting untuk memperoleh kemampuan-kemampuan berbahasa lainnya. Hal tersebut sejalan dengan pendapat Al-Nughaimish (2011) bahwa pada umumnya setiap hari pelajar menggunakan waktu komunikasinya yaitu 55\% untuk mendengarkan, $23 \%$ untuk berbicara, $13 \%$ untuk membaca dan $8 \%$ untuk menulis.

Mendengar merupakan proses dasar dari menyimak, dengan melatih kemampuan menyimak berarti membantu seseorang meningkatkan kemampuan mendengarnya. Umumnya seorang anak akan menggunakan bahasa yang sering didengar atau disimaknya dalam kehidupan sehari-hari. Dengan menyimak, seseorang dapat mengetahui informasi yang disampaikan oleh orang lain secara tepat. Karena seorang pendengar atau penyimak yang baik diharapkan mampu menyampaikan informasi yang baik pula.

Peranan penting dari kemampuan menyimak harus disadari oleh setiap pengajar bahasa, pemahaman bahwa kemampuan menyimak dapat diperoleh secara spontan harus dihilangkan. Karena pada dasarnya, untuk menjadi penyimak yang baik, kemampuan itu harus dilatih. Menurut Martaulina (2018) salah satu cara untuk melatih kemampuan menyimak adalah dengan menggunakan media pembelajaran. Seperti yang kita ketahui bahwa media pembelajaran merupakan segala sesuatu yang dapat digunakan untuk menyampaikan pesan atau informasi kepada siswa. Selain itu, media pembelajaran juga dapat membantu proses belajar siswa menjadi lebih efektif.

Mendengar dan menyimak tentunya dua hal yang berbeda, meskipun keduanya saling terikat satu sama lain. Apabila seseorang menyimak sudah pasti ia mendengar, namun seseorang yang mendengar belum tentu menyimak. Smaldino (2011: 381) menyebutkan "Mendengar adalah proses fisiologi dan menyimak adalah proses psikologis". Secara fisiologis, mendengar adalah proses masuknya gelombang suara ke telinga bagian luar dan dipancarkan ke gendang telinga, kemudian telinga bagian luar mengubahnya menjadi getaran, lalu diubah menjadi sinyal di telinga bagian dalam yang bergerak menuju ke otak. Sedangkan proses psikologis dari menyimak dimulai dari kesadaran dan perhatian seseorang tentang suara atau pola pembicaraan (menerima), yang dilanjutkan dengan identifikasi makna, dan berakhir dengan pemahaman (mengerti). Sejalan dengan pendapat di atas, Anaktatoty (2016) menyimpulkan bahwa dalam berkomunikasi, menyimak adalah salah satu keterampilan berbahasa yang menjadi faktor penting dalam mendukung keberhasilan aktivitas pribadi, akademik, dan profesi. Aktivitas sehari-hari mengharuskan kita untuk berinteraksi dan berkomunikasi dengan orang lain secara baik. Oleh karena itu, kemampuan menyimak sangat diperlukan agar informasi yang diperoleh dari orang lain atau sebaliknya dapat direspon dengan baik pula.

Menurut Rosdia (2013) menyimak adalah mendengarkan lambang bunyi yang dilakukan secara sadar dan disengaja disertai dengan perhatian, pemahaman, dan apresiasi untuk memperoleh suatu informasi sehingga dapat merespon apa yang diperolehnya. Peranan penting dari kemampuan menyimak harus harus disadari oleh setiap pengajar bahasa, pemahaman bahwa kemampuan menyimak diperoleh secara spontan harus dihilangkan karena pada dasarnya kemampuan itu harus dilatih. Salah satu cara untuk melatih kemampuan menyimak menurut Martaulina (2018) adalah dengan menggunakan media pembelajaran.

Kata media berasal dari bahasa Latin dan merupakan bentuk jamak dari kata medium yang secara harfiah berarti tengah, perantara atau pengantar. Hal ini sejalan dengan pendapat yang dikemukakan oleh Sadiman, dkk (2010: 6) "Media adalah perantara atau pengantar pesan dari pengirim ke penerima pesan." Dalam dunia pendidikan media diartikan sebagai sarana yang digunakan pendidik untuk mengantarkan pesan atau informasi kepada siswa. Media dapat berupa sesuatu bahan (software) dan/atau berupa alat (hardware).

Menurut Asosiasi Pendidikan Nasional (National Education Association/NEA) dikutip dalam Sadiman, dkk (2010: 7) bahwa media adalah

Segala bentuk komunikasi baik tercetak maupun audiovisual serta peralatannya. Media dapat dimanipulasi, dilihat, didengar, dan dibaca. Meskipun terbagi kedalam beberapa jenis terdapat persamaan yang menjadi dasar yaitu bahwa media adalah segala sesuatu yang dapat digunakan untuk menyampaikan informasi dari pengirim kepada penerima. 
Sehingga dapat merangsang pikiran, perasaan, perhatian dan minat belajar siswa dalam proses belajarnya.

"Media pembelajaran adalah segala bentuk peralatan fisik yang didesain secara terencana untuk menyampaikan informasi dan membangun interaksi. Peralatan fisik yang dimaksud berupa benda konkret, bahan cetak, visual, audio, audio-visual, multimedia dan jaringan web" Yaumi (2018: 7). Peralatan tersebut dirancang dan dikembangkan agar sesuai dengan kebutuhan belajar peserta didik. Media pendidikan merujuk pada saluran komunikasi yang membawa pesan untuk tujuan pembelajaran. Media dimanfaatkan untuk tujuan belajar dan mengajar. Menurut Prastowo (Syawaluddin, et.al., 2019) salah satu kompetensi yang harus dimiliki oleh seorang guru adalah mengembnagkan materi pembelajaran secara kreatif dengan memanfaatkan teknologi informasi dan komunikasi untuk berkomunikasi dan pengembangan diri.

Penggunaan media secara kreatif akan memperbesar kemungkinan bagi siswa untuk belajar lebih banyak, menanamkan apa yang dipelajarinya lebih baik, dan meningkatkan penampilan dalam melakukan keterampilan sesuai dengan tujuan pembelajaran.

Media audio oleh Riyana (2012) mengemukakan bahwa media audio merupakan media yang menjadikan suara/bunyi sebagai kekuatan utamanya. Suara yang dihasilkan diharapkan dapat memberi gambaran secara jelas terhadap pendengarnya seolah-olah mereka membayangkan bentuk, suasana, dan rasa yang ia tangkap melalui imajinasinya.

Sejalan dengan pengertian tersebut, Niswardi \& Ambiyar (2016: 16) mengemukakan pengertian media audio sebagai berikut:

Media audio berupa pesan yang disampaikan atau dituangkan ke dalam simbol-simbol auditif, yang melibatkan rangsangan indera pendengaran. Karakteristik media audio antara lain: mampu mengatasi keterbatasan ruang dan waktu (mudah dipindahkan dan jangkauannya luas), pesan/program dapat direkam dan diputar kembali sesukanya, dapat mengembangkan daya imajinasi dan merangsang partisipasi aktif pendengarnya, dapat mengatasi masalah kekurangan guru, sifat

komunikasinya hanya satu arah, sangat sesuai untuk pengajaran musik dan bahasa....

Salah satu media yang dapat digunakan dalam pengajaran menyimak adalah podcast. Menurut Smaldino, dkk (2011: 371) "Podcasting atau podcast berasal dari kata "iPod" dan "broadcasting/penyiaran" yang merupakan file rekaman audio dalam format MP3 yang disebarkan melalui internet". Sedangkan menurut Shera (2010: 35) dalam bukunya menyatakan bahwa podcast adalah website yang menyediakan media komunikasi berupa suara seperti siaran radio yang dapat diunduh dan didengarkan kapan saja. Salah satu jurnal internasional yang ditulis oleh Abdullah, dkk (2017) menyebutkan bahwa podcast hampir sama dengan radio namun terdapat beberapa karakteristik podcast yang membedakannya dengan radio. Podcast memberikan akses kepada pendengarnya untuk memilih program/konten yang digemarinya, pendengar juga dapat mengunduhnya secara otomatis sehingga dapat didengarkan kapanpun dan dimanapun.

Beberapa penelitian menunjukkan bahwa podcast merupakan media yang dapat digunakan dalam pembelajaran menyimak. Podcast menjadi inovasi baru bagi perkembangan media, khususnya media pembelajaran berbasis audio. Materi atau konten yang terdapat dalam podcast sangat beragam mulai dari konten ekonomi, budaya, berita, olahraga, kesehatan, komedi, bisnis, keluarga dan pendidikan. Guru dapat memanfaatkan media ini untuk digunakan dalam pembelajaran dan tentunya menarik untuk digunakan siswa karena merupakan suatu hal yang baru bagi mereka. Kehadiran podcast juga diharapkan dapat membawa teknologi pendidikan di Indonesia menjadi lebih baik.

Podcast termasuk dalam media pembelajaran berupa audio (rekaman suara) yang tersedia di internet. Podcast hampir sama dengan siaran radio, perbedaannya yaitu podcast dapat diunduh karena tersedia di internet sehingga mudah untuk didengarkan kapan saja dan dimana saja. Penggunaan podcast dalam pembelajaran diharapkan dapat menarik perhatian siswa untuk belajar, khususnya belajar menyimak. Dengan demikian kemampuan menyimak siswa dapat digunakan semaksimal mungkin.

Salah satu penelitian yang dilakukan oleh Qasim \& Fadda (2013) menunjukkan 
bahwa podcast dapat digunkan sebagai media pembelajaran karena memberikan pengaruh yang signifikan terhadap kemampuan menyimak. Podcast termasuk dalam media pembelajaran berupa audio yang tersedia di internet.. Fadilah, dkk (2017) mengutip dalam kamus Oxford istilah podcast diartikan sebagai file audio dalam bentuk digital yang tersedia di internet biasanya berseri atau berepisode, dapat diunduh ke komputer atau media pemutar portable seperti telepon genggam secara gratis ataupun berlangganan.

Kenyataan yang terjadi di sekolah dasar khususnya pada pembelajaran bahasa Indonesia materi menyimak cerita, penggunaan media podcast masih sangat jarang digunakan. Hal ini disebabkan minimnya pengetahuan tentang adanya podcast. Sebagai inovasi baru dalam media audio, podcast dapat menjadi salah satu alternatif bagi guru yang mempunyai keterbatasan dalam berbicara . Misalnya guru tersebut tidak dapat mengucapkan bunyi huruf secara jelas maka ia dapat memanfaatkan podcast dalam proses pembelajarannya. Penggunaan podcast dalam pembelajaran diharapkan dapat menarik perhatian siswa untuk belajar, khususnya belajar menyimak. Sehingga kemampuan menyimak siswa dapat digunakan semaksimal mungkin.

Berdasarkan uraian diatas, peneliti tertarik mengadakan penelitian tentang pengaruh media podcast terhadap kemampuan menyimak cerita pada pembelajaran bahasa Indonesia siswa SD Negeri 55 Parepare. Adapun tujuan penelitian ini yaitu untuk mengetahui pengaruh media podcast terhadap kemampuan menyimak cerita pada pembelajaran bahasa Indonesia siswa SD Negeri 55 Parepare.

\section{METODE PENELITIAN}

Penelitian ini menggunakan metode pendekatan kuantitatif dengan jenis penelitian eksperimen. Desain yang digunakan yaitu Quasy Eksperimental Design atau desain eksperimen semu dengan bentuk the nonequivalent pretestposttest control group design. Penelitian ini akan menggunakan dua kelas, yaitu kelas eksperimen dan kelas kontrol, kedua kelas tersebut akan diberikan pretest dengan tujuan untuk mengetahui keadaan awal siswa. Setelah itu, pada kelas eksperimen akan diberikan perlakuan berupa pembelajaran dengan media podcast sedangkan pada kelas kontrol berlangsung secara konvensional. Pada akhir penelitian dilakukan posttest untuk melihat kemampuan menyimak siswa setelah diberi perlakuan.

Adapun variabel bebasnya atau yang memberi pengaruh adalah media podcast sedangkan variabel terikatnya atau yang diberi pengaruh adalah kemampuan menyimak. Populasi dalam penelitian ini adalah seluruh siswa SD Negeri 55 Parepare yaitu sebanyak 355 orang siswa, teknik sampling yang digunakan adalah purposive sampling. Sampel yang diambil yaitu siswa kelas IV SD Negeri 55 Parepare sebanyak 46 orang siswa yang terdiri dari 2 kelas yaitu kelas IV A sebagai kelas kontrol dan IV B sebagai kelas eksperimen, masing-masing kelas tersebut mempunyai jumlah 23 orang siswa.

Teknik pengumpulan data yang digunakan yaitu tes dan dokumentasi. Tes yang diberikan adalah tes tertulis dengan bentuk pilihan ganda. Teknik analisis data yang digunakan ada dua, yaitu analisis statistik deskriptif dan analisis statistik inferensial. Untuk analisis statistik inferensial terdapat dua uji yang digunakan yaitu uji prasyarat data dan uji hipotesis. Sebelum melakukan uji hipotesis terlebih dahulu dilakukan uji prasyarat data yaitu uji normalitas dan homogenitas. Setelah kedua uji prasyarat data memenuhi syarat maka dilakukan uji hipotesis.

\section{HASIL DAN PEMBAHASAN}

1. Hasil statistik deskriptif

a. Pretest kelas eksperimen

Rata-rata nilai yang diperoleh dengan jumlah 23 orang siswa yaitu 39,13 dengan nilai median 40 dan modus 40. Sedangkan standar deviasi yang diperoleh 13,11 dengan nilai minimum 20 dan nilai maksimum 60 .

\section{b. Pretest kelas kontrol}

Rata-rata nilai yang diperoleh dengan jumlah 23 orang siswa yaitu 40,87 dengan nilai median 40 dan modus 40. Sedangkan standar deviasi yaitu 13,11 dengan nilai minimum 20 dan nilai maksimum 60 .

\section{c. Posttest kelas eksperimen}

Rata-rata nilai yang diperoleh yaitu 68,26 dengan nilai median 70 dan modus 70 . Sedangkan standar deviasi yang diperoleh yaitu 13,36 dengan nilai minimum 40 dan nilai maksimum 90.

d. Posttest kelas kontrol

Rata-rata nilaiyang diperoleh dengan jumlah 23 orang siswa yaitu 41,74 dengan median 40 dan modusi 20. Seangkan standar 
deviasi yang diperoleh yaitu 17,74 dengan nilai minimum 20 dan nilai maksimum 70 .

Berikut adalah gambaran hasil pretest dan posttest kelas eksperimen dan kontrol yang disajikan dalam diagram batang.

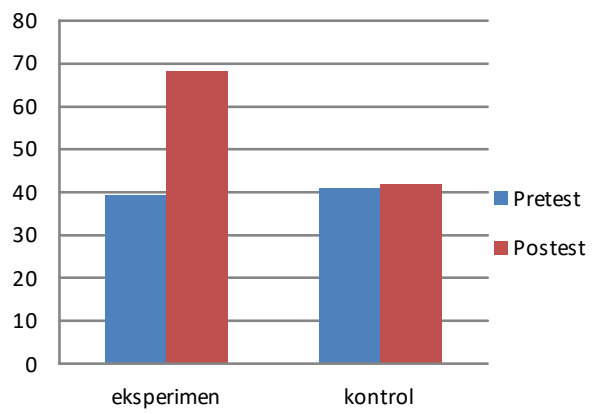

Gambar 1. Diagram Batang Rata-rata (Mean) Pretest dan Posttest Kelas Eksperimen dan Kontrol

Dari diagram diatas menunjukkan nilai posttest kelas eksperimen yang diberikan pengajarakan dengan media podcast lebih tinggi dibandingkan kelas kontrol yang pembelajarannya berlangsung secara konvensional.

2. Hasil statistik inferensial

Sebelum pengujian hipotesis terlebih dahulu dilakukan uji prasyarat data yaitu uji normalitas dan uji homogenitas. Untuk uji normalitas diperoleh koefisien signifikasi data lebih besar dari 0,05 yang menunjukkan bahwa sebaran data berdistribusi normal. Untuk uji homogenitas diperoleh signifikansi lebih besar dari 0,05 yang menunjukkan bahwa data yang diperoleh berasal dari populasi yang homogen. Uji prasyarat data telah terpenuhi sehingga uji hipotesis dengan menggunakan paired sample $t$ test dapat dilakukan.

Berdasarkan data diperoleh bahwa $-\mathrm{t}_{\text {tabel }}$ $<\mathrm{t}_{\text {hitung }}(-9.898<-2,074)$ dan signifikansi , 0,05 $(0,000<0,05)$. Dengan demikian $\mathrm{H}_{0}$ ditolak dan $\mathrm{H}_{\mathrm{a}}$ diterima yang berarti terdapat pengaruh penggunaan media podcast terhadap kemampuan menyimak cerita pada pembelajaran bahasa Indonesia siswa kelas IV SD Negeri 55 Parepare.

Hasil analisis tersebut menunjukkan bahwa perubahan nilai yang cukup besar pada kelas eksperimen disebabkan karena kelas eksperimen diberikan perlakuan berupa pembelajaran dengan media podcast dimana dalam proses pembelajaran siswa memfokuskan perhatiannya terhadap podcast (rekaman) yang diputarkan. Cerita-cerita yang disajikan saat proses pembelajaran menarik bagi siswa karena setiap cerita mengandung nilai-nilai pendidikan yang mudah dan dekat dengan kehidupan siswa. Serta pembelajaran dengan media podcast merupakan hal baru bagi siswa sehingga mereka merasa semangat dalam mengerjakan tugas kelompok maupun mengikuti pembelajaran.

Menurut Qasim \& Fadda (2013) bahwa pembelajaran menyimak dapat dipelajari dengan memanfaatkan teknologi, yaitu podcast. Penggunaan podcast dapat memberikan pengaruh yang cukup signifikan terhadap kemampuan menyimak. Podcast dapat memberikan suasana pembelajaran yang menyenangkan bagi siswa, khususnya dalam menyimak. Hal tersebut sejalan dengan penelitian yang dilakukan oleh Fitria (2014) yang menunjukkan bahwa podcast disajikan bermakna, tepat, kegiatan dan materi yang bisa menarik perhatian siswa, meningkatkan motivasi mereka, dan meningkatkan pemahaman mereka dalam menyimak. Oleh karena itu, podcast dapat dijadikan sebagai media pembelajaran berbasis teknologi yang efektif dan inovatif dalam pembelajaran menyimak di kelas.

\section{SIMPULAN DAN SARAN}

Berdasarkan rumusan masalah dan hasil penelitian diperoleh bahwa antara nilai rata-rata pretest dan posttest siswa pada kelas eksperimen mengalami peningkatan yang cukup besar setelah diberi treatment berupa pembelajaran dengan media podcast. Sehingga dapat ditarik kesimpulan bahwa terdapat pengaruh pemberian media podcast terhadap kemampuan menyimak cerita pada pembelajaran bahasa Indonesia siswa kelas IV SD Negeri 55 Parepare.

Adapun saran yang dapat diajukan yaitu 1) bagi guru, setelah mengetahui pembelajaran dengan media podcast dapat digunakan untuk melatih kemampuan menyimak siswa maka perlu memperhatikan materi podcast yang sesuai dengan materi yang akan dipelajari siswa karena sudah banyak tersedia podcast khusus pendidikan; 2) Bagi siswa, agar dengan media podcast ini dapat memfokuskan perhatian siswa dalam belajar khususnya menyimak, kontenkonten yang tersedia di podcast juga dapat menarik perhatian siswa apalagi media ini merupakan suatu hal yang jarang digunakan; 3) Bagi peneliti, dapat memperluas wawasan dan pengetahuan serta dapat dijadikan sebagai bahan referensi untuk melanjutkan penelitian. Hal ini perlu dilakukan agar proses pembelajaran dimasa yang akan datang dapat lebih inovatif 
dan berkembang sesuaidengan kemajuan zaman yang semakin modern.

\section{DAFTAR RUJUKAN}

Abdullah, T. 2017. The Impact of Podcast on EFL Students Listening Comprehension. Internasional Jurnal of Language Education, 2: 23-32.

Al-Nughaimish, M. I. 2011. Terampil Mendengarkan. Kemang Timur: Zaman.

Anaktatoty, K. 2016. Teori Pembelajaran Bahasa. Yogyakarta: Garudhawaca.

BNSP. 2013. Permendiknas RI No. 22 tentang Standar Isi untuk Badan Nasional Satuan Pendidikan Dasar dan Menengah. Jakarta: BNSP

Fadilah, E., Yudhapramesti, P., \& Aristi, N. 2017. Podcast sebagai Alternatif Distribusi Konten Audio. Kajian Jurnalisme, 1 (1): 90-103.

Fitria, Uti. 2014. Meningkatkan Podcast untuk Meningkatkan Listening Siswa. Acedemia Edu.

Martaulina, S. D. 2018. Bahasa Indonesia Terapan. Yogyakarta: Deepublish.

Qasim, \& Fadda. 2013. The Effectiveness of Podcast in Listening Class. Jurnal Humaniora, 13 (2): 171-173.

Rosdia. 2013. Peningkatan Kemampuan Menyimak Melalui Metode Mendongeng. Jurnal Kreatif Tadulako, 4: 250-267.

Sadiman, A., Rahardjo, R., Haryono, A., \& Rahardjito. 2010. Media Pendidikan: Pengertian, Pengembangan, dan Pemanfaatannya. Jakarta:Rajawali Pers.

Shera, A. 2010. Step By Step Internet Marketing. Jakarta: Elex Media Komputindo.

Smaldino, S. E., Lowther, D. L., \& Russell, J. D. 2011. Teknologi Pembelajaran dan Media untuk Belajar. Jakarta: Kencana. Jakarta: Kencana.

Susanto, A. 2013. Teori Belajar dan Pembelajaran di Sekolah Dasar. Jakarta: Kencana.

Syawaluddin, A., Andi M., \& Ina F. J. 2019. Pengembangan Media Pembelajaran Berbasis Aplikasi Lectora Inspire Pada Mata Pelajaran IPS Kelas V Di SDN 197 Sapolohe Kecamatan Bontobahari Kabupaten Bulukumba. JIKAP PGSD: Jurnal Ilmiah Ilmu Kependidikan, 3 (3): 294-306.

DOI: http://doi.org/10.26858/jkp.v1i1.

$$
\underline{5158}
$$

Yaumi, M. 2018. Media dan Teknologi Pembelajaran. Jakarta: Prenada Media Group. 